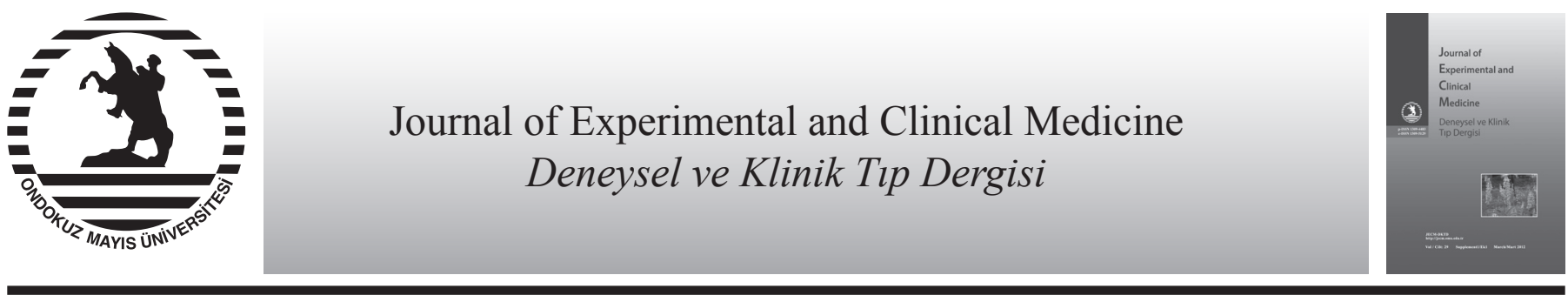

Derleme / Review

doi: $10.5835 /$ jecm.omu.29.s1.006

\title{
Oral antidiyabetik ajanlar
}

Oral antidiabetic agents

Gülçin Cengiz Ecemiş, Hulusi Atmaca*

Ondokuz Mayıs Üniversitesi, Tıp Fakültesi Endokrinoloji Bilim Dall, Samsun, Türkiye

\begin{tabular}{|c|c|}
\hline МАКА & GÍLERİ \\
\hline Makal & \\
\hline Geliş & 13 / $01 / 2011$ \\
\hline Kabul & 15 / 02 / 2011 \\
\hline * Yazış & \\
\hline Hulusi & \\
\hline Ondok & Üniversitesi Tıp Fakültesi \\
\hline $\begin{array}{l}\text { Endokr } \\
\text { e-posta }\end{array}$ & $\begin{array}{l}\text { ilim Dalı, Samsun, Türkiye } \\
\text { (ayahoo.com }\end{array}$ \\
\hline
\end{tabular}

\section{Anahtar Kelimeler:}

Diabetes Mellitus

Sülfonilüreler

Sekretagoglar

Biguanidler

-Glukozidaz İnhibitörleri

Tiazolidindionlar

\section{Keywords:}

Diabetes Mellitus

Sulphonylureas

Secretagogues

Biguanides

$\alpha$-Glucosidase Inhibitors

Thiazolidinediones

\section{ÖZET}

Diabetes mellitus tüm dünyada prevalansı gittikçe artan kronik bir hastalıktır. Farmakolojik tedavi optimal glisemik kontrolü sağlamak için çoğu zaman gereklidir. Günümüzde klinisyenlere tip 2 diyabet tedavisi için çok geniş yelpazede oral antidiyabetik ilaçlar sunulmaktadır. Bu oral antidiyabetik ilaçlar; insülin sekresyonunu stimüle edenler (sülfonilüreler ve hızlı etkili sekretagoglar), hepatik glukoz üretimini azaltanlar (biguanidler), intestinal karbonhidrat sindirimi ve emilimini geciktirenler ( $\alpha$-glukozidaz inhibitörleri) ve insülin etkisini iyileştirenler (tiazolidindionlar) olarak ayrılabilir. Bu makalede farklı oral antidiyabetik ilaçların etki mekanizmaları, etkinlikleri ve yan etkileri ile birlikte kullanımları ile ilgili en son öneriler tartışılacaktır. J. Exp. Clin. Med., 2012; 29:S23-S29

\begin{abstract}
Diabetes mellitus is a chronic disease that is growing in prevalence worldwide. Pharmacologic therapy is often necessary to achieve optimal glycemic control in the management of diabetes. Today's clinicians are presented with an extensive range of oral antidiabetic drugs for type 2 diabetes. These main drug classes include agents that stimulate insulin secretion (sulphonylureas and rapid-acting secretagogues), reduce hepatic glucose production (biguanides), delay digestion and absorption of intestinal carbohydrate ( $\alpha$-glucosidase inhibitors) or improve insulin action (thiazolidinediones). We review the mechanism of action, efficacy and side effects of the different classes of oral antidiabetic drugs and discuss the current recommendations for their use.

J. Exp. Clin. Med., 2012; 29:S23-S29
\end{abstract}

Tip 2 diabetes mellitus'da (DM) hem insülin sekresyonunda yetersizlik, hem de insülin duyarlılığında azalma (insülin direnci) vardır. Bunlardan hangisinin primer olduğu tam olarak açıklanamamıştır. Tip 2 DM'de hiperglisemi iki farklı ve birbirleriyle ilişkili mekanizma ile belirgin hale gelir. Hepatik glukoz yapımındaki artış nedeniyle açlık plazma glukozunda yükselme, insülin sekresyonunda ve periferik kullanımında bozukluk sonucu postprandiyal glukozda artış ortaya çıkar. Günümüzde mevcut oral antidiyabetikler bu patofizyolojik bozuklukların bir veya daha fazlasında etkilidirler (Çorakçı ve ark., 2009). Şu anda kullanımda olan farklı temel oral antihiperglisemik sınıfları; insülin sekresyonunu arttıranlar, insülin direncini azaltanlar ve gastrointestinal sistemden glukoz giriş hızını değiştiren ajanlar olarak bölünebilir. Oral antidiyabetiklerin özellikleri Tablo 1'de gösterilmiştir. (Lebovitz, 2005).

\section{İnsülin sekresyonu üzerine etkili ilaçlar}

İnsülin sekretagogları pankreas beta $(\beta)$ hücresinin plazma membranında adenozin trifosfat (ATP) bağımlı potasyum $\left(\mathrm{K}^{+}\right)$kanallarını (KATP) kapatarak insülin sekresyonunu uyarır. KATP kanalı sülfonilüre 1 reseptörünün (SUR-1) fonksiyonel kompleksidir. Kir-6,2 alt ünitesi iç kısmında yer alan yönlendiriciyi oluşturur ve $\mathrm{K}^{+}$bu alt üniteden geçerek intrasellüler kompartmandan extrasellüler kompartmana aktarılır. SUR-1 ünitesi Kir-6,2 alt ünitesine bağlanmıştır ve KATP kanalının açık ya da kapalı olup olmamasını düzenler. Bu kanalların inhibisyonu ile potasyumun hücre içinden hücre dışına çıkışı önlenir ve hücre membranı depolarize olur. Hücre membran depolarizasyonu sonucu voltaj bağımlı kalsiyum kanalları açılarak hücre dışından kalsiyumun hücre içine girişi artar ve bu durum insülin sekresyonunun stimülasyonuna yol açar (Bressler ve Johnson, 1997; Lebovitz, 2005). 


\begin{tabular}{|c|c|c|c|c|c|}
\hline İlaç grubu & Etki Mekanizması & Doz & $\begin{array}{c}\text { HbA1c' deki } \\
\text { azalma }\end{array}$ & Yan Etki & Kontrendikasyonlar \\
\hline Metformin & $\begin{array}{l}\text { Karaciğer ve kasta insülin } \\
\text { duyarlılığını arttırır, Hepatik } \\
\text { glukoz üretimini azaltır }\end{array}$ & $2 \times 1000 \mathrm{mg}$ & $\% 1-1,5$ & $\begin{array}{l}\text { Gastrointestinal, laktik } \\
\text { asidoz }\end{array}$ & $\begin{array}{l}\text { Orta-şiddetli karaciğer ve kardiyak } \\
\text { disfonksiyon, hafif renal disfonksiyon }\end{array}$ \\
\hline $\begin{array}{l}\text { Sülfonilüreler } \\
\text { (Gliklazid, } \\
\text { Glimepirid) }\end{array}$ & İnsülin sekresyonunu arttırırlar & $\begin{array}{l}\text { Gliklazid MR 1x30- } \\
\text { 120mg, Glimepirid } \\
\text { 1x1-8mg }\end{array}$ & $\% 1-1,5$ & Hipoglisemi, kilo artışı & $\begin{array}{l}\text { Orta-şiddetli karaciğer disfonksiyonu, } \\
\text { şiddetli böbrek disfonksiyonunda doz } \\
\text { ayarlanır }\end{array}$ \\
\hline $\begin{array}{l}\text { Non- } \\
\text { sülfonilüreler } \\
\text { (Repaglinid, } \\
\text { Nateglinid) }\end{array}$ & $\begin{array}{l}\text { İnsülin sekresyonunu akut } \\
\text { olarak arttırır }\end{array}$ & $\begin{array}{l}\text { Repaglinid } 3 \times 0,5-4 \mathrm{mg}, \\
\text { Nateglinid } 3 \times 60- \\
\text { 120mg }\end{array}$ & $\begin{array}{l}\text { Repaglinid } \\
\% 1-1,5 \\
\text { Nateglinid } \\
\% 0,5-1\end{array}$ & Hipoglisemi, kilo artışı & $\begin{array}{l}\text { Şiddetli karaciğer ve böbrek } \\
\text { disfonksiyonu }\end{array}$ \\
\hline Pioglitazon & $\begin{array}{l}\text { Adipoz dokuda ve kasta İnsülin } \\
\text { duyarlılığını arttırır }\end{array}$ & $15-45 \mathrm{mg} 1 \mathrm{x} 1$ & $\% 1-1,5$ & $\begin{array}{l}\text { Kilo artışı, ödem, } \\
\text { anemi, pulmoner } \\
\text { ödem, konjestif kalp } \\
\text { yetmezliği }\end{array}$ & $\begin{array}{l}\text { Şiddetli karaciğer yetmezliği, NYHA } \\
\text { class II-IV }\end{array}$ \\
\hline Akarboz & $\begin{array}{l}\text { İntestinal karbohidrat emilimini } \\
\text { geciktirir }\end{array}$ & $\begin{array}{l}\text { 1x25mg ile başlanıp } \\
\text { 3x100mg'ye çıkı1ır }\end{array}$ & $\% 0,5-1$ & Gastrointestinal & $\begin{array}{l}\text { İrritabl bağırsak sendromu, ciddi } \\
\text { karaciğer ve böbrek disfonksiyonu }\end{array}$ \\
\hline
\end{tabular}

\begin{tabular}{|c|c|c|c|c|}
\hline Sülfonilüreler & $\begin{array}{c}\text { Günlük doz } \\
\text { (mg) }\end{array}$ & $\begin{array}{l}\text { Etki } \\
\text { süresi }\end{array}$ & $\begin{array}{l}\text { Metabolitlerinin } \\
\text { aktivitesi }\end{array}$ & $\begin{array}{c}\text { Eliminasyon } \\
\text { yolu }\end{array}$ \\
\hline \multicolumn{5}{|l|}{ 1. Jenerasyon } \\
\hline Klorpropamid & $100-500$ & Uzun & aktif & $>\% 90$ idrar \\
\hline Tolbutamid & $500-2000$ & Kisa & inaktif & $\% 100$ idrar \\
\hline \multicolumn{5}{|l|}{ 2. Jenerasyon } \\
\hline $\begin{array}{l}\text { Glibenklamid } \\
\text { (Gliburid) }\end{array}$ & $2,5-15$ & $\begin{array}{l}\text { Orta- } \\
\text { uzun }\end{array}$ & aktif & $\% 50$ safra \\
\hline Glimepirid & $1-6$ & Orta & aktif & $\% 80$ idrar \\
\hline Glipizid & $2,5-20$ & $\begin{array}{l}\text { Kisa- } \\
\text { uzun }\end{array}$ & inaktif & $\% 70$ idrar \\
\hline Gliquidone & $15-180$ & $\begin{array}{l}\text { Kisa- } \\
\text { uzun }\end{array}$ & inaktif & $\% 95$ safra \\
\hline Gliklazid & $30-120$ & Orta & inaktif & $\% 65$ idrar \\
\hline
\end{tabular}

Tüm insülin sekretagoglarının insülin sekresyonunu uyarmadaki ve hiperglisemiyi azaltmadaki etkinliği fonksiyon gösteren $\beta$ hücrelerine bağımlıdır. İnsülin sekretagogları tip 1 diyabetli, erişkin latent otoimmün diyabeti olan hastalarda ve pankreatik $\beta$ hücre fonksiyonu belirgin yetersiz olan tip 2 diyabetin geç evrelerinde olan hastalarda etkisizdir. KATP kanallları beyin, miyokard, vasküler düz kas hücresi olmak üzere diğer birçok dokuda mevcuttur. Beyin KATP kanalının SUR alt ünitesi pankreatik $\beta$ hücresi ile aynı iken miyokard ve vasküler düz kas hücresindeki izoformlar farklıdır (SUR-2A ve SUR-2B). Sülfonilürelerin hepsi ve non sülfonilüre insülin sekretogogları meglitinidler, KATP kanalına farklı bölgelerden bağlanarak farklı dinamiklerin gelişmesine neden olur. Bu durum farmakolojik farklılıklar ile sonuçlanır ve yan etki profillerinde klinik farkl11ıklara yol açar (Cheng ve Fantus, 2005; Lebovitz, 2005).

\section{Sülfonilüreler}

Sülfonilüreler 1950 'lerden itibaren kullanılmaktadır. İkinci jenerasyon sülfonilüreler (gliburid, glipizid, glimepirid) 1. jenerasyon sülfonilürelere göre (klorpropamid, tolbutamid, asetohekzamid ve tolazamid) daha potent ve muhtemelen daha güvenlidir (Inzucchi, 2002).

Sülfonilüreler $\beta$-hücrelerindeki reseptörlerine bağlandıklarında (SUR-1) daha önceden yapılmış insülin granüllerinin hızlı bir şekilde salınımıyla birlikte granüllerin uzatılmış salınımını (ikinci faz) da uyarırlar (Levetan, 2007). Sonuç olarak açlık plazma glukozunu düşürmekle birlikte postprandial plazma glukozunu da düşürürler. $\beta$-hücresinin fonksiyonuna bağlı olarak ilaç aktif olduğu müddetçe salınım devam eder. (Levetan, 2007). İnsülin sekresyonunu arttırıcı etkileri kan glukoz konsantrasyonuna bağlı değildir. Bu nedenle fonksiyon gören $\beta$ hücresi olan diyabetlilerde etkilidir (Çorakçı ve ark., 2009). Sülfonilüre ilaçları insülin biyosentezini arttırmamakta ve hatta proinsülin biyosentezini in vitro inhibe ediyor gibi gözükmektedir. $\beta$-sitotropik ya da $\beta$-hücre tükenmesini kolaylaştırdıklarına dair kanıt yoktur (Lebovitz, 2005). Ayrıca hepatik insülin klirensini azaltarak serum insülin konsantrasyonunu arttırırlar. İnsülin düzeyinin artması hepatik glukoz üretimini suprese eder (Harrigan ve ark., 2001). Esas etkileri açlık hiperglisemilerini düzeltmektir. Sülfonilüreler karaciğerde metabolize edilirler. Metabolitleri ile birlikte sülfonilüre tipleri arasında eliminasyon yolları açısından farlılıklar vardır. Proteinlere yüksek oranda bağlandıkları için proteinlere bağlanan salisilat, sülfonamid, varfarin gibi diğer ilaçlarla etkileşebilirler (Levetan, 2007). Birinci jenerasyon sülfonilüreler $\% 90$ 'dan fazla oranda plazma proteinlerine bağlanırlar ve ikinci jenerasyon sülfonilürelerle karşılaştırıldıklarında kullanıldıkları doz miligram olarak göz önüne alındığında daha az potenttirler.

İkinci jenerasyon sülfonilüreler ise plazma proteinlerine iyonik olarak bağlanmazlar ve ilaç etkileşimi daha az belirgindir. Tüm sülfonilüreler maksimum etkili dozda kullanıldıklarında genellikle benzer şekilde etki gösterirler (Çorakçı ve ark., 2009). Terapötik etkilerini önerilen maksimal dozun yarısında göstermektedirler. Lipid düzeyini ve kan basıncını etkilemezler. Hemoglobin A1c (HbA1C)'yi \%1-2 oranında düşürürler (Inzucchi, 2002; Mizuno ve ark., 2008). Tip 2 diyabetik hastaların \%10-20'sinde ineffektiftirler (Mizuno ve ark., 2008). Hastalar tedavi başlanmasını takiben ilk ay içinde bu ilaca cevap vermezler. Buna 'primer sülfonilüre yetersizliği' denir (Çorakçı ve ark., 2009). Sülfonilüreler insülin sekresyonunu artırarak etki gösterirler. Fakat zamanla insülin sekretuar kapasitesinde progressif bir kayıp görülür. $\mathrm{Bu}$ azalma 'sekonder yetersizlik' olarak tanımlanır ve bu durum sülfonilüre tedavisinin $\beta$ hücrelerinde yol açtığı yorgunluk ve reseptör downregülasyonu ile ilişkilendirilmiş̧ir (Harrower, 1994; Harrower, 2000). Ayrıca yüksek glukoz düzeyleri glukotoksisite ile insülin sekretuar fonksiyonlarının kaybına yol açar. Sekonder sülfonilüre yetersizliği gelişen hastaların $\geq \% 10$ 'unda glutamik asid dekarboksilaz antikoru ve adacik hücre antikoru pozitifliği saptanmıştır. Sülfonilüre grupları arasında sekonder yetersizlik oranları farklılık gösterir. İki- 
yüz kırk sekiz tip 2 diyabetik hastanın 5 yıl izlendiği bir çalışmada sekonder yetersizlik oranları gliklazid ile $\% 7$, glibenklamid ile $\% 17,9$ ve glipizid ile $\% 25,6$ olarak saptanmıştır (Harrower, 1994).

Farklı sülfonilüre tipleri arasında birtakım farklılıklar bulunmaktadır. Plazma insülin artışııın kan şekerini düşürme aktivitesine oranı glimepirid $<$ glipizid $<$ gliklazid $<$ glibenklamid şeklindedir. Glibenklamid günde tek doz verilirken glipizid iki kez verilir. Glibenklamid bazal insülin sekresyonunu glipizide göre daha fazla arttırır ve bu nedenle hipoglisemi riski glipizide göre daha fazladır. Miligram dozları karşılaştırıldığında glibenklamid glipizide göre iki kat daha potent etkiye sahiptir (Rendell, 2004). Her ne kadar sülfonilüreler gebelikte kullanılamasalar da gestasyonel diyabetli hastalarda gliburid ile insülinin etkinliklerinin karşılaştırıldığı bir çalışmada insüline benzer şekilde etkinlik ve güvenilirliği olduğu gösterilmiştir (Langer ve ark, 2005). Sülfonilürelerin en önemli yan etkileri hipoglisemi ve kilo artışıdır. İnsülin salınımı üzerindeki etkileri plazma glukoz düzeyinden bağımsız olduğu için hipoglisemi riski tüm sülfonilürelerde görülür (Cheng ve Fantus, 2005). Sülfonilüre tedavisi ile plazma insülin düzeyindeki artışa bağlı olarak 2-5 kg kadar kilo alımı görülür (Cheng ve Fantus, 2005). İkinci jenerasyon ajanlardan glimepirid ve glipizid ile tedavi edilenlerde kilo alımı ve hipoglisemi riski gliburid ile tedavi edilenlere göre daha az görülür (Levetan, 2007). Sülfonilüreler karaciğerde metabolize edildikleri için orta-ciddi karaciğer yetmezliğinde kontrendikedir. Orta düzeyde böbrek yetmezliği olan yaşlı hastalarda gliburid dozunun azaltılması gerekirken, gliklazid ve glimepirid için doz ayarlanmasına gerek yoktur (Lebovitz, 2001). Farklı sülfonilüre tiplerinin metabolik özellikleri Tablo 1'de belirtilmiştir. Yan etkileri arasında ayrıca; hepatotoksisite (enzimlerde yükselme, sarılık, kolestaz), alerjik reaksiyonlar (kaşıntı, eritema nodozum, fotosensitivite) hematolojik anormallikler (hemolitik anemi, trombositopeni, agranülositoz) ve gastrointestinal şikayetler (bulantı, kusma, yanma) görülebilir (Çorakçı ve ark., 2009). Sülfonamid bazlı antibiyotiklerle çapraz reaksiyon göstererek alerjik reaksiyon oluşturabilirler (Nyenwe ve ark., 2011). Özellikle birinci jenerasyon sülfonilürelerde (Klorpropamid) alkol alımından yarım saat kadar sonra bazı hastalarda yüz ve boyunda kızarma (flushing), renal hücrelerin anti-diüretik hormona duyarlılığının artması sonucu dilüsyonel hiponatremi görülebilir (Çorakçı ve ark., 2009).

\section{Sülfonamidler ve kardiyovasküler sistem}

İki çeşit sülfonilüre reseptörü bulunmaktadır. SUR-1 ve SUR-2a/b. İkinci tip reseptörler miyokardiyum ve koroner düz kas hücrelerinde bulunmaktadırlar ki KATP kanalları ile yakın ilişki göstererek miyokardiyumun iskemik ön hazırl1ğında major rol oynarlar (Nyenwe ve ark, 2011). Benzamid grubu içeren sülfonilüreler (glibenklamid, glipizid, glimepirid) SUR-2a ve 2b'ye bağlanabilirken, benzamido grubu içermeyenler (tolbutamid, klorpropamid, gliklazid) kardiyak ve vasküler SUR reseptörleri ile minimal etkileşim gösterirler (Krentz ve Bailey, 2005). KATP kanalları kardiyak hücrelerde ve koroner damarlarda bulunduğu için myokardial infarkt sırasında sülfonilürelerin bulunmasının yeterli koroner vasodilatasyonu engelleyebileceği ve bu nedenle miyokardiyal hasarı artırabileceği tahmin edilmektedir. Diğer hipotezler sülfonilüre tedavisinin iskemik ön hazırlıkla etkileşebilece- ği ve muhtemel aritmojenik etkileri olduğudur (Bell, 2006). Geniş, prospektif, randomize klinik çalışmalar (ACORD, ADOPT, DREAM, VADT, RECORD) sülfonilüre alan hastalarda artmış bir kardiyovasküler risk olduğunu göstermemişlerdir. Her ne kadar miyokardiyal infarktüslü hastalarda sülfonilüre tedavisinin mortaliteyi arttırdığı gösterilmese de, özellikle bu hasta grubunda insülin infüzyonunun faydalı olduğu bilindiği için miyokardiyal hipoksili hastalarda SUR-2 ligandlarına olan yüksek afiniteyi engellemek için dikkatli olunmalidır (Nyenwe ve ark, 2011).

\section{Meglitinidler (Glinidler)}

Meglitinidler, repaglinid (benzoik asid türevi) ve nateglinid (fenilalanin türevi) non-sülfonilüre insülin sekretagoglarıdır ve sülfonilürelere benzer mekanizma ile etki gösteririler (Rendell, 2004). Hızlı bir şekilde absorbe edilmeleri ve KATP kanallarına hızlı bağlanma kinetikleri ile özellikle erken dönem yemekle ilişkili insülin salınımını arttırarak postprandial plazma glukozunu azaltırlar (Inzucchi, 2002). Sülfonilüre reseptörlerine farklı bölgeden ve farklı kinetikle bağlanarak benzer şekilde insülin salınımını uyarırlar. Etkileri daha hızlı başlar, yarılanma ömürleri daha kısadır. Karaciğerde sitokrom P450 enzim sistemi tarafindan metabolize edilerek safra ile atılmaktadırlar. Repaglinid sülfonilürelere benzer etkinlik gösterirken, nateglinid sülfonilürelerden daha az etkinlik göstererek HbA1C'yi \% 0,5-1 oranında düşürürler (Cheng ve Fantus, 2005). Repaglinid ile nateglinidin monoterapideki etkinliklerinin karşılaştırıldığı 16 hafta süren bir çalışmada; HbA1c'deki düşüş repaglinid ile \%1,57 iken nateglinid ile $\% 1,04$ olarak saptanmıştır (Rosenstock ve ark., 2004). Repaglinidin insülin uyarıcı etkisi sülfonilürelerden farklı olarak yalnızca glukoz varlı̆ı̆ında mümkündür. Repaglinid plazma proteinlerine yüksek oranda bağlanır (\%95). Metabolize olan \%98'lik kısmın \%90'1 safra yolu ile feçesle ve \%8'i idrarla atılmaktadır. $\mathrm{Bu}$ nedenle repaglinidin metabolizması neredeyse tamamen böbrek fonksiyonundan bağımsızdır, hafif ve orta dereceli böbrek yetmezliğinde kullanılabilir. Oral alımı takiben hızlı absorbe edilmekte ve 5-10 dk içerisinde kan dolaşımında saptanabilmektedir (Rendell, 2004). Repaglinidin insülin salgılama etkisi $30 \mathrm{dk}$ içinde başlar ve erken yemek aracılı insülin sekresyonunu kolaylaştırır (Lebovitz, 2005). Yarılanma ömrü kısa olduğu için postprandiyal dönemde hipoglisemi riski düşüktür.

Sonuç olarak etkileri sülfonilürelere göre daha hızlı başlamakta ve daha kısa sürmektedir (ortalama 4-6 saat). Her öğünden önce 0,5-4 mg dozda uygulanabilir (Rendell, 2004). Repaglinidin metabolizması sitokrom P450 izoenzimi olan CYP 3A4 tarafından gerçekleştirildiği için bu enzim aktivitesini değiştiren diğer ilaçlarla kullanımında dikkatli olunmalıdır. Gemfibrozil CYP 3A4'ün inhibitörü olduğu için repaglinid ile birlikte kullanımında uzamış hipoglisemi riski artar. Nateglinid ise esas olarak CYP 2C9 sistemince metabolize olduğu için gemfibrozil ile etkileşmemektedir (Cheng ve Fantus, 2005). Nateglinid ince bağırsaktan çok hızlı bir şekilde absorbe edilir. Biyoyararlanım $1 \% 72$ 'dir. Plazma proteinlerine yoğun bir şekilde bağlanır ve karaciğerde metabolize edilir. Etkisi sülfonilürelere ve repaglinidlere göre çok daha hızlı başlar ve daha kısa sürer. Bu nedenle özellikle postprandiyal hiperglisemide etkilidir ve hipoglisemi daha az görülür. İnsülin sekresyonunu arttırıcı etkisi sülfonilürelerden farklı olarak ortamdaki glukoza bağımlıdır. Genellikle günde $3 \mathrm{kez}$ 
yemeklerden $10 \mathrm{dk}$ önce $120 \mathrm{mg}$ dozda verilir. Her iki ilacın en önemli yan etkisi hipoglisemidir. Etki mekanizmaları ortamdaki glukoza bağlı olduğu için öğün atlanması durumunda ilacın o öğün için alınmamasına dikkat edilmelidir (Krentz ve Bailey, 2005).

\section{Periferik dokularda insülin duyarlılığını arttıran ilaçlar} 1. Metformin

Tip 2 diyabetin tedavisinde 1960'lı y1llardan beri kullanılmakta olan bir biguaniddir (Lebovitz, 2005). İki molekül guanidin içerir. Doğada Galega officinalis, Fransız leylağı ya da sedef otu olarak bilinen bitkide bulunur (Şek. 1).

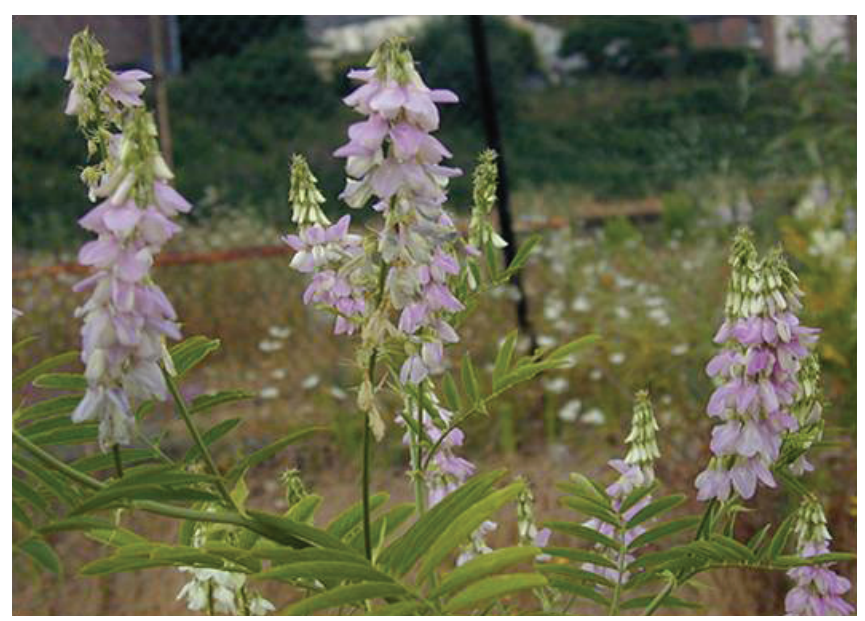

Şek. 1. Galega officinalis, Fransız leylağı, Sedef otu

Laktik asidoz gibi yan etkileri nedeniyle fazla kullanılmayan diğer guanidin deriveleri fenformin ve buformin ile yapısal benzerlik gösterir (Çorakçı ve ark., 2009). Amerikan Diyabet Birliği (ADA) ve Avrupa Diyabet Çalışma Birliği (EASD)'nin son konsensusunda; diyabet tanısı konulduğunda diyet ve yaşam tarzı değişiklikleri ile birlikte kullanımı için herhangi bir kontrendikasyon yoksa metformin tedavisine başlanması önerilmiştir (ADA, 2011). Metforminin hücre içi hedefi AMP tarafindan aktive olan protein kinaz, anahtar proteinlerin fosforilasyonu yolu ile AMP-aktive protein kinaz (AMPK) glukoz ve lipid metabolizmasında ve hücresel enerji regülasyonunda rol oynar (Krentz ve Bailey, 2005). Metformin yalnızca insülin varlığında etkilidir ve esas etkisi hepatik glukoz çıkışını azaltmaktır. Ayrıca kas ve karaciğer gibi periferik dokularda özellikle yemeklerden sonra insülin aracılı glukoz utilizasyonunu arttırır. Antilipolitik etki ile serum serbest yağ asidi konsantrasyonunu düşürür (Bailey ve Turner, 1996). Plazma trigliserid, yağ asidi, düşük dansiteli lipoprotein (LDL) kolesterol düzeylerinde azalmaya, yüksek dansiteli lipoprotein (HDL) kolesterol düzeyinde artışa neden olur. Lipid profilindeki iyileşme insülin duyarlılığında ve glukoz-yağ asidi siklusunda yararlı olmasına rağmen bu etkinin antihiperglisemik etkiden bağımsız olduğu düşünülmektedir (Krentz ve Bailey, 2005). Glisemik kontrolün sağlanması ile serum insülin seviyelerinde hafifçe düşme meydana gelir (Çorakçı ve ark., 2009). Metformin tarafindan hepatik glukoz üretiminde azalma, temel olarak glukoneogenezde azalmaya bağlı olmakla beraber glukojenolizdeki azalmanın da katkısı mevcuttur. Metforminin pankreatik $\beta$ hücreleri üzerinde direkt etkisi yoktur ve insülin sekresyonunu direkt olarak etkilemez, sadece plazma glukoz seviyelerinin değiştirilmesi üzerinden etkileri mevcuttur. Bu nedenle hipoglise- mik değil antihiperglisemiktir. (Lebovitz, 2005). Metformin deneysel hayvan çalışmalarında non-oksidatif metabolizma yolu ile intestinal glukoz kullanımını arttırdığı gösterilmiştir. $\mathrm{Bu}$ işlemde laktat üretilmektedir ve laktatın büyük kısmı glukoneogenez için substrat oluşturur ve karaciğerde metabolize edilir. Bu durumun hipoglisemiyi önleyici etkileri olduğu düşünülmektedir (Çorakçı ve ark., 2009). Metforminin metabolik ve vasküler etkileri Tablo 3 'te belirtilmiştir.

Tablo 3. Metforminin metabolik ve vasküler etkileri (Krentz ve Bailey, 2005)

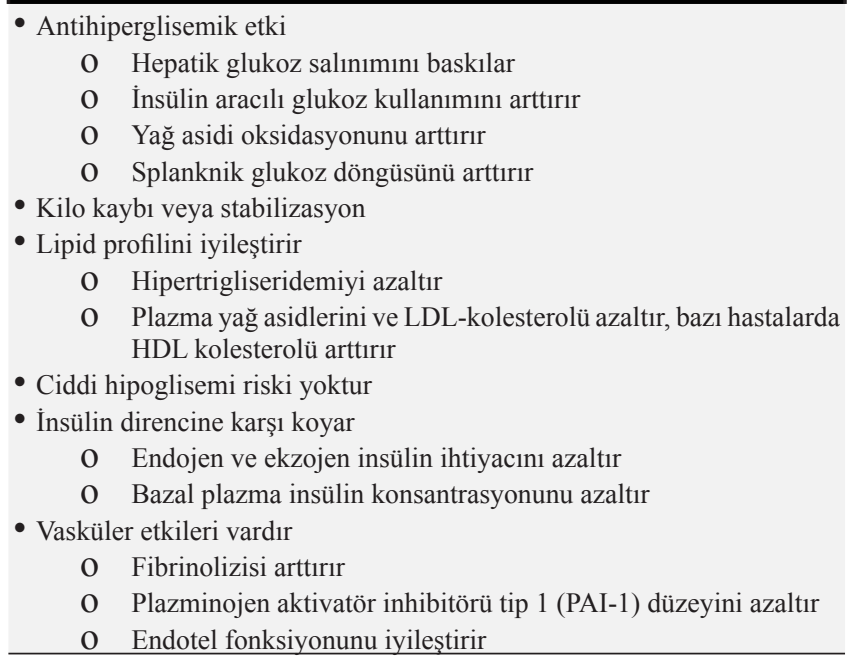

Metformin ince bağırsaktan emilir ve pik plazma konsantrasyonuna yaklaşık 2 saat içinde ulaşır. Plazma proteinlerine bağlanmaz, plazma yarılanma ömrü 1,5-4,9 saattir, metabolize edilmez ve böbrekler tarafından hızlıca temizlenir (12 saat içinde \%90) (Bailey ve Turner, 1996; Lebovitz, 2005). Tip 2 diyabetik hastalarda glisemik kontrol üzerinde metformin etkisine ait doz yanıt çalışmaları maksimum etkinin günlük 1700-2000 mg dozlarda ortaya çıktığını göstermiştir. Metformin günde 2 kez yemekle birlikte alınır, böylece gastrointestinal yan etkiler en aza iner (Lebovitz, 2005).

Metformin, etki mekanizması tamamen farklı olsa da sülfonilürelere benzer şekilde açlık plazma glukozunda $\% 20$ oranında ve HbA1C'de \%1,5 oranında azalmaya neden olur (Hermann ve ark., 1994). Bu etki $\beta$ hücre fonksiyonunun varlığına bağlı olmakla birlikte yaş, vücut ağırlığı ve diyabet süresinden bağımsızdır (Krentz ve Bailey, 2005). Obez hastalarda ağırlığın azalmasını, en azından stabilizasyonunu sağlar (Hermann ve ark, 1994). Genellikle ilk 6 ay içerisinde ortalama 2,5-4,5 kg'lık bir düşme sağlanır ve bu vücut ağırlığı devam edebilir. Kilo kaybının oluşmasında ilacın direkt olarak iştah merkezini etkileyerek anoreksiye neden olduğu, gıdaların bağırsaktan absorbsiyonunu etkilediği veya termogenezi arttırdığı gibi nedenler ileri sürülmüştür. Metformin etkisinin başlaması hızlı değildir. Tedavi başladıktan sonraki 2-3 gün içerisinde kan glukozu düşmeye başlar ve 2 haftada pik değere erişir. Metformin alan hastaların çoğunda plazma insülin konsantrasyonu düşer (Çorakçı ve ark., 2009).

İnsülin ve insülin benzeri büyüme faktörleri (IGF) birçok normal ve transforme hücre tiplerinde proliferasyonu uyardığı gibi bu reseptörler aracılığıyla sinyalizasyonu stimüle eden ajanların da proliferasyonu arttırması beklenmektedir (Nyenwe ve ark., 2011). Son yapılan popülasyon çalışmala- 
rından elde edilen bilgilere göre metforminin bazı kanserlerin insidansını azalttığı ve prognozda iyileşmeye yol açtığı görülmüştür. Bir çalışmada metformin kullanan diyabetik hastalarda diğer tedavileri alan diyabetik hastalara göre kanser riskinin daha az olduğu görülmüştür (Evans ve ark., 2005). Yine bir başka çalışmada metformin kullanan diyabetik hastalarda sülfonilüre ve insülin tedavisi alan hastalara göre kansere spesifik mortalitede azalma gözlenmiştir (Bowker ve ark., 2006).

Metformin tedavisinin en önemli yan etkileri gastrointestinal sistem ile ilişkili olarak mide bulantısı, ishal, kramp şeklinde karın ağrısı ve metalik tatdır. Semptomların yaklaşık 1/3'ü tedavinin başlangıcında görülür. Bu yan etkiler yemeklerden sonra düşük dozda tedaviye başlanması ve dozun yavaşça artırılması ile en aza indirgenebilir (Buse ve ark., 2008). Laktik asidoz çok ender olması ve hemen her zaman metforminin kontrendike olduğu durumlarda ortaya çıkmasına rağmen, en çok korkulan komplikasyondur. Metformin alan hastalarda bildirilen laktik asidoz insidans $3 / 100000$ olmakla beraber ölüm oranı \%50'dir. Metformin tedavisi esnasında laktik asidoz gelişen vakaların hemen tümü bozulmuş renal fonksiyonu olan hastalarda veya renal fonksiyonların bozulmasına yol açacak hastalığı olan vakalarda ortaya çıkmıștır. Metformin bu hastalarda kontrendikedir (Lebovitz, 2005). Metformin gebelikte B grubu risk sınıfına girmektedir (ADA, 2011). Metformin hastaların yaklaşık \%30'unda vitamin B12'nin intestinal emilimini azaltır ve vitamin B12 konsantrasyonunu \%5-10 oranında düşürür. Nadiren megaloblastik anemiye neden olur. Vitamin B12 eksikliği ileumdan emilimin azalmasına bağlıdır ve metforminin kullanım doz ve süresi ile ilişkilidir. Bu durum oral kalsiyum alımı ile düzelebilir (Bauman ve ark., 2000; Ting ve ark., 2006). Metformin tedavisinin kontrendikasyonları Tablo 4'de özetlenmiştir.

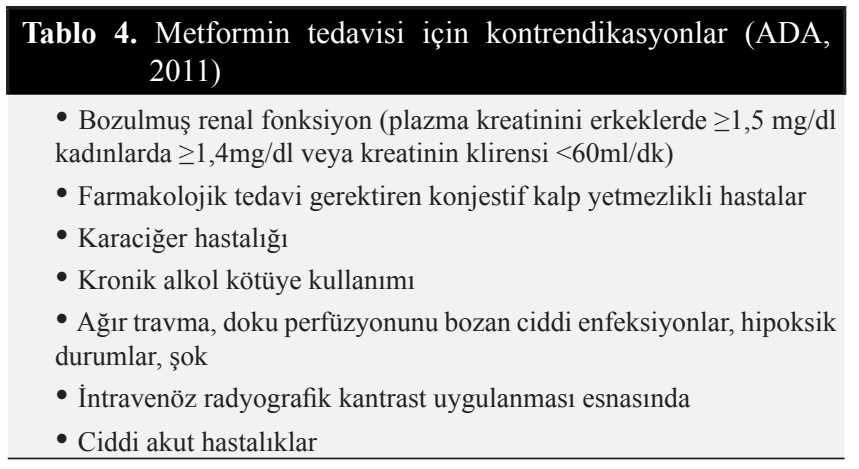

\section{Tiazolidindionlar}

Tiazolidindionlar ilk olarak 1970'li yılların sonuna doğru keşfedilmiştir. Çeşitli türevler geliştirildikten sonra 3 molekül; troglitazon, rosiglitazon, pioglitazon klinik kullanım için onay almıştır. Piyasaya ilk çıkan tiazolidindion troglitazon olmasına rağmen ender de olsa hepatik yetmezlik ve ölüme ilerleyebilecek idiosinkratik karaciğer toksisitesi gelişimi ile ilişkisi bulunması üzerine 2000 yılında kullanımdan çekilmiştir (Lebovitz, 2005). Rosiglitazon ise tip 2 diyabetik hastalarda kalp krizi ve inme gibi kardiyovasküler olay riskini arttırdığı gerekçesi ile 2010'da piayasadan geri çekilmiştir.

Tiazolidindionlar adipoz doku, kas ve karaciğerde glukoz kullanımını arttırıp üretimini azaltarak insülin duyarlılığını arttırırlar (Yki-Järvinen, 2004). Etkilerini nükleer reseptör olan ve makrofajlar ve adipositlerde yaygın olarak bulunan
PPAR (peroksizom proliferatör aktive edici reseptör) aktivasyonu ile gösterirler (Masharani ve German, 2007). Üç farklı alt grubu PPAR $\alpha, \operatorname{PPAR} \delta$ ve PPAR $\gamma$ tanımlanmıştır. Çoklu doymamış yağ asitleri ve fibratlar, esas olarak karaciğer, kalp, iskelet kası ve vasküler duvarlarda eksprese edilen PPAR $\alpha$ reseptörlerine bağlanarak HDL-kolesterolü arttırıp trigliseridi azaltırlar (Yki-Järvinen, 2004). PPAR $\gamma$ esas olarak adipoz doku, pankreatik $\beta$-hücrelerinde, vasküler endotelde ve makrofajlarda bulunur. Troglitazon ve rosiglitazon sadece PPAR $\gamma$ 'ya bağlanırken, pioglitazon PPAR $\gamma$ 'nın yanında PPAR- $\alpha$ üzerinden de etki gösterir (Park ve ark., 1997). Tiazolidindionlar, insülin varlığında kas ve yağ dokusunda glukoz alımını GLUT-1 ve GLUT-4 reseptör ekspresyonunu, insülin sinyalizasyonunu, glukojen sentaz aktivitesini arttırırken, serbest yağ asidlerini, trigliserit klirensini, hepatik glukoneogenezi ve TNF- $\alpha$ 'yı azaltır. Preadipositlerin adipositlere dönüşümünü arttırarak adipoz dokuyu yeniden yap1landırır (Çorakçı ve ark., 2009). Tiazolidindionlar PPAR $\gamma$ aktivasyonu ile insülin duyarlılığını ve insülin direncini iyileştirerek, kalp kası, iskelet kası ve adipoz dokuya glukoz alımını arttırıp karaciğerden glukoz çıkışını azaltır (Mizuno ve ark., 2008). PPAR $\gamma$ aracılığ 1 ile lipogenezin stimulasyonu dolaşımdaki non-esterifiye yağ asidi konsantrasyonunu azaltır. Non-esterifiye serbest yağ asidi konsantrasyonundaki azalma artmış glukoz utilizasyonu, azalmış glukoneogenezis, kas ve karaciğerdeki azalmış ektopik lipid depozisyonu ile ilişkilidir. Tiazolidindionlar aynı metformin gibi antihiperglisemik ajanlardır. Bu nedenle antihiperglisemik etki için yeterli insülin varlığına ihtiyaç duyarlar (Krentz ve Bailey, 2005). PPAR $\gamma$ 'nın konsantrasyonu obezlerin ve diyabetik hastaların iskelet kaslarında artmıştır. Artmış konsantrasyon serum insülin konsantrasyonu ile koreledir. Tiyazolidindionlar, glukoz transport aktivitesini kolaylaştırarak tip 2 diyabetli hastalarda iskelet kasının insülin cevabını düzeltirler (Park ve ark., 1997).

Biyoyararlılığ $1 \% 83$ olup iyi absorbe olur ve plazma proteinlerine bağlanma oranı $>\% 97$ ' dir. Plazma yarılanma ömrü 5-6 saat olmasına rağmen aktif metabolitleri nedeniyle glukoz düşürücü etkisi 16-23 saat kadar devam edebilir. Hepatik sitokrom P450 ile metabolize edilir ve esas olarak safra yolu ile atılır. Günde bir kez 15-45 mg dozlarında öğünlerle ilişkisiz olarak kullanılır. HDL kolesterolde belirgin artma, trigliserid ve serbest yağ asidlerinde düşme gözlenirken, total kolesterol ve LDL kolesterolde belirgin bir değişiklik gözlenmez (YkiJärvinen, 2004; Çorakçı ve ark., 2009). HbA1C'de \%0,5-1,4 oranında düzelmeye neden olurlar. Teropatik etkilerin ortaya çıkabilmesi için 12 haftaya kadar beklemek gereklidir (Mizuno ve ark., 2008).

Tiazolidindionlar esas olarak insülin duyarlılığını arttırarak kan şekerini düzelttikleri için insülin ve sülfonilüreye göre daha az hipoglisemiye neden olurlar (Aronoff ve ark., 2000). Kullanıldıkları doz ve süre ile ilişkili olarak kilo al1mına neden olurlar. Kilo alımı çoğunlukla sıvı retansiyonu nedeniyle olmakla birlikte yeni adiposit proliferasyonu sonucu da gelişebilir (Basu ve ark., 2006). Sıvı retansiyonu özellikle insülin ile kombine kullanıldığı durumlarda oldukça önemlidir (Mizuno ve ark., 2008). Bu nedenle New York Heart Association'a (NYHA) göre class 3 ve 4 kalp yetmezliği bulunanlarda kullanılmamalıdır (Nyenwe ve ark, 2011). En önemli yan etkilerinden biri hepatotoksisitedir. İlaç kullanımı sırasında periodik olarak karaciğer fonksiyon testleri ta- 
kibi yapılmalıdır (Mizuno ve ark, 2008). Bilinen bir karaciğer yetmezliği olan ya da karaciğer fonksiyon testleri bozuk olan (ALT $>2,5)$ hastalarda kontrendikedir (Krentz ve Bailey, 2005). Anemi, kilo alımı ve ödem diğer önemli yan etkilerinden biridir (Mizuno ve ark., 2008). Aneminin nedeni yaklaşı \% $15^{\prime}$ lere kadar varan intravasküler volüm ekspansiyonu nedeniyle muhtemelen dilüsyoneldir (Mizuno ve ark., 2008). Ödemin nedenleri; vazodilatasyon, artmış renal sodyum absorbsiyonu, artmış plazma volümü ve refleks sempatik aktivasyondur (Mizuno ve ark., 2008). Tiazolidindion ilişkili natretansiyonu, $\mathrm{K}^{+}$tutucu diüretik veya hidroklorotiazid ile tedavi ile düzelir (Nyenwe ve ark., 2011). Pioglitazonun maksimum dozu 45mg'dır ve hafif-orta böbrek yetmezliğinde doz ayarlamasına gerek olmadan kullanılabilir (Krentz ve Bailey, 2005).

Tiazolidindionlar, özellikle kadınlarda kemik dansitesini azaltır, kırık riskini arttırır. Kadın ve erkeklerde femur ve non-vertebral osteoporotik kırıkları 2-3 kat arttırdığı görülmüştür. Bu etki azalmış osteoblastik kemik formasyonu ve artmış kırık riski ile ilişkilidir. Risk artı̧ı özellikle 2 yıldan sonraki kullanımlarda belirginleşir. Bu nedenle özellikle osteoporozu olan hastalarda kullanılması önerilmemektedir (Meier ve ark., 2008).

\section{Tiazolidindionların kardiyovasküler etkileri}

Lipid profili: Dolaşımdaki serbest yağ asitlerini azaltır, LDL-kolesterol partikül boyutunu arttırır, lipoprotein A'y1, HDL kolesterolü arttırır, LDL/HDL oranını ve trigliseridleri azaltır

Koagülasyon ve fibrinolizis: Plazminojen aktivatör inhibitörü tip 1 (PAI-1) düzeyini ve aktivitesini azaltır, patelet agregasyonunu azaltır, fibrinojeni ve endotelin-1'i azaltır.

Vasküler parametreler: Koroner akış rezervini arttırır, nabız dalga hızını azaltır, intima-media kalınlığını, endotelial fonksiyonu ve idrar albümin atılımını artırır.

Hemodinamik parametreler: İntravasküler volümü arttırır, kan basıncını azaltır.

Yağ dağılımı: Visseral yağı ve hepatik yağ içeriğini azaltır, subkütanöz yağı arttırır (Stafylas ve ark., 2009).

\section{Gastrointestinal sistemde karbohidrat emilimini azal-} tan ilaçlar liboz)

Alfa-glukozidaz inhibitörleri (Akarboz, miglitol, vog-

İlk olarak 1996 y1lında tip 2 diyabet tedavisinde kullan1ma giren akarboz, saflaştırılmış mikrobiyal kaynaklı bir psödotetrasakkarittir. Sadece gastrointestinal kanalda etki eder ve postprandiyal glukozu düşürür (Lebovitz, 2005; Mizuno ve ark., 2008).

Kompleks karbohidratlar ince bağırsakta amilaz tarafından oligosakkaridlere ayrışrr. Oligosakkaridlerin emilmeden önce monosakkaridlere ayrışması gereklidir. Oligosakkaridler enterositlerin firçamsı kenarında bulunan alfa glukozidaz enzimleri (glukoamilaz, sükraz, maltaz, dekstrinaz ve izomaltaz) tarafindan monosakkaridlere ayrışırlar. Normalde karbohidratlar primer olarak hızlı bir şekilde distal duodenum ve proksimal jejunumdan absorbe olurlar. Alfa glukozidaz inhibitörleri, kompetitif olarak reversibl bir şekilde enzime bağlanarak, karbohidrat absorbsiyonu ve emilimini geciktirir ve gastrointestinal yol boyunca sürmesini sağlar. Böylece hem tip 1 hem de Tip 2 DM'de postprandial plazma glukozunda azalmaya neden olur. Farklı alfa glukozidaz inhibitörlerinin etki mekanizması benzerdir. Akarbozun izomaltaz üzerine çok az etkisi vardır, $\beta$-glukozidaz enzimi olan laktaz üzerine hiçbir etkisi yoktur (Lebovitz, 2005; Çorakçı ve ark., 2009). Alfa glukozidaz inhibitörleri glukozun emilimini etkilemez, emilim yerini gastrointestinal sistemde daha distale kaydırır (Krentz ve Bailey, 2005). Glukoz emilimin gecikmesi $\beta$ hücrelerine insülin salınımını arttırması için zaman kazandııır (Mizuno ve ark., 2008).

Akarboz sülfonilüre ve metforminden daha az etkilidir. HbA1C'yi \%0,7-1 oranında, postprandiyal glukozu 18-72 $\mathrm{mg} / \mathrm{dl}$ civarında düşürür (Krentz ve Bailey, 2005; Mizuno ve ark., 2008). Tedavide etkinlik ilk haftada görülmeye başlar ve uzun dönem devam eder (DeFronzo, 1999). Akarbozun absorbsiyonu iyi değildir. Plazmada aktif bileşik ancak \% 1-2 düzeyine ulaşır (Lebovitz, 2005). Akarboz ince bağırsaktaki amilaz ve bakteriler tarafından parçalanır. İdrardan 24 saatte atılır (Krentz ve Bailey, 2005). Alfa glukoz inhibitörlerinin en önemli avantajı bağırsakta lokal etki gösterip sistemik etkilerinin olmamasıdır. $\mathrm{Bu}$ nedenle özellikle ileri yaşlı diyabetik hastalarda uygundur. Kilo alımına ve hipoglisemiye yol açmazlar (Mizuno ve ark., 2008). Akarboz her öğünün başlangıcında ilk lokma ile alınmalı, öğünler kompleks karbohidratlardan zengin olmalıdır. Günde $25-50 \mathrm{mg}$ dozda günde tek öğün ile başlanıp doz yavaş bir şekilde arttırılmalıdır. Maksimum doza (3x100 mg) çıkmaktaki en önemli engel gastrointestinal yan etkileridir. İnce bağırsakta karbohidrat sindirimi ve emiliminin gecikmesi ile oligosakkaridler kalınbağırsağa geçer. Bakteriler ile karbohidratlar fermentasyona uğrar ve kısa zincirli yağ asidleri, hidrojen gazı, metan ve karbondioksit üretilir (Lebovitz, 2005; Krentz ve Bailey, 2005). Bu durum karın ağrısı, gaz ve diare gibi gastrointestinal semptomlara neden olur. Titrasyon sirasında gastrointestinal yan etkiler ön plana çıkarsa yan etkiler zamanla azalacağı için bazen doz azaltılmasıyla sorun çözülebilir (DeFronzo, 1999). Hastaların \%25-45'inde yan etkiler nedeniyle ilaç kesilmesi gerekebilir (Mizuno ve ark., 2008). Yüksek dozlarda kullanıldığında karaciğer enzimlerinde yükselmeye yol açabilir (Levetan, 2007). Bağırsak motilitesini etkileyen ilaçlar potansiyel olarak akarbozun etkinliğini ve gastrointestinal yan etkilerini etkiler ve kolestiramin akarbozun antihiperglisemik etkilerini azaltır (Krentz ve Bailey, 2005). Alfa glukozidaz inhibitörlerinin kullanımı, inflamatuvar bağırsak hastalığı ve malabsorbsiyonda kontrendikedir. Ayrıca ileri böbrek yetmezliğinde de kullanılmamalıdır.

\section{KAYNAKLAR}

American Diabetes Association. 2011. Diabetes Care. 34, 1-96.

Aronoff, S., Rosenblatt, S., Braithwaite, S., Egan, J.W., Mathisen, A.L., Schneider, R.L., 2000. Pioglitazone hydrochloride monotherapy improves glycemic control in the treatment of patients with type 2 diabetes: A 6-month randomized placebo-controlled dose-response study. Diabetes Care. 23, 1605-1611.

Bailey, C.J., Turner, R.C., 1996. Metformin. N. Engl. J. Med. 334, 574-579. 
Basu, A., Jensen, M.D., McCann, F., Mukhopadhyay, D., Joyner, M.J., Rizza, R.A, 2006. Effects of pioglitazone versus glipizide on body fat distribution, body water content, and hemodynamics in type 2 diabetes. Diabetes Care. 29, 510-514.

Bauman, W.A., Shaw, S., Jayatilleke, E., Spungen, A.M., Herbert, V., 2000. Increased intake of calcium reverses vitamin B12 malabsorption induced by metformin. Diabetes Care. 23, 1227-1231.

Bell, D.S., 2006. Do sulfonylurea drugs increase the risk of cardiac events? CMAJ. 174, 185- 186.

Bowker, S.L., Majumdar, S.R., Veugelers, P., Johnson, J.A., 2006. Increased cancer-related mortality for patients with type 2 diabetes who use sulfonylureas or insulin. Diabetes Care. 29, 254-258.

Bressler, R., Johnson, D.G., 1997. Pharmacological regulation of blood glucose levels in non- insulin-dependent diabetes mellitus. Arch. Intern. Med. 157, 836-848.

Buse, J.B., Polonsky, K.S., Burant, C.F., 2008. Type 2 Diabetes Mellitus, in Williams Textbook of Endocrinology, Vol 30, Kronenberg HM, Melmed S, Polonsky KS, Larsen PR eds, Saunders Elsevier, Philadelphia, pp. 1329-1389.

Cheng, A.Y., Fantus, I.G., 2005. Oral antihyperglycemic therapy for type 2 diabetes mellitus. CMAJ. 172, 213-226.

Çorakçı A, Azal Ö, Beyhan Z, 2009. Diabetes Mellitus'ta Oral Ajan Tedavisi, in Diabetes Mellitus 2009 Multidisipliner Yaklaşımla Tanı, Tedavi ve İzlem, Vol 9, İmamoğlu Ş, Ersoy Özyardımcı C eds, Deomed, İstanbul, 137-176

DeFronzo, R.A., 1999. Pharmacologic therapy for type 2 diabetes mellitus. Ann. Intern. Med. 131, 281-303.

Evans, J.M., Donnelly, L.A., Emslie-Smith, A.M., Alessi, D.R., Morris, A.D., 2005. Metformin and reduced risk of cancer in diabetic patients. BMJ. 330, 1304-1305.

Harrigan, R.A., Nathan, M.S., Beattie, P., 2001. Oral agents for the treatment of type 2 diabetes mellitus: Pharmacology, toxicity, and treatment. Ann. Emerg. Med. 38, 68-78.

Harrower, A.D., 1994. Comparison of efficacy, secondary failure rate, and complications of sulfonylureas. J. Diabetes Complicat. 8, $201-203$.

Harrower, A.D., 2000. Comparative tolerability of sulphonylureas in diabetes mellitus. Drug Saf. 22, 313-320.

Hermann, L.S., Scherstén, B., Bitzén, P.O., Kjellström, T., Lindgärde, F., Melander, A., 1994. Therapeutic comparison of metformin and sulfonylurea, alone and in various combinations. A double-blind controlled study. Diabetes Care. 17, 1100-1109.

Inzucchi, S.E., 2002. Oral antihyperglycemic therapy for type 2 diabetes: Scientific review. JAMA. 287, 360-372.

Krentz, A.J., Bailey, C.J., 2005. Oral antidiabetic agents: Current role in type 2 diabetes mellitus. Drugs. 65, 385-411.

Langer, O., Yogev, Y., Xenakis, E.M., Rosenn, B., 2005. Insulin and glyburide therapy: Dosage, severity level of gestational diabetes, and pregnancy outcome. Am. J. Obstet. Gynecol. 192, 134-139.

Lebovitz, H.E., 2001. Oral therapies for diabetic hyperglycemia. Endocrinol. Metab. Clin. North Am. 30, 909-933.

Lebovitz, H.E., 2005. Management of hyperglycemia with oral antihyperglycemic agents in Type 2 diabetes, in Joslin's Diabetes Mallitus, Vol 41, Kahn CR, Weir GC, King GL, Jacobson AM, Moses AC, Smith RJ eds, Lipincott Williams \& Wilkins, Boston, pp. 687-710.

Levetan, C., 2007. Oral antidiabetic agents in type 2 diabetes. Curr. Med. Res. Opin. 23, 945-952.

Masharani, U., German, M.S., 2007. Pancreatic Hormones \& Diabetes Mellitus, in Greenspan's Basic \& Clinical Endocrinology, Vol 18, Gardner DG, Shoback D eds, McGraw-Hill Company, USA, pp. 661-747.

Meier, C., Kraenzlin, M.E., Bodmer, M., Jick, S.S., Jick, H., Meier, C.R., 2008. Use of thiazolidinediones and fracture risk. Arch. Intern. Med. $168,820-825$.

Mizuno, C.S., Chittiboyina, A.G., Kurtz, T.W., Pershadsingh, H.A., Avery, M.A., 2008. Type 2 diabetes and oral antihyperglycemic drugs. Curr Med. Chem. 15, 61-74.

Nyenwe, E.A., Jerkins, T.W., Umpierrez, G.E., Kitabchi, A.E., 2011. Management of type 2 diabetes: Evolving strategies for the treatment of patients with type 2 diabetes. Metabolism. 60, 1-23.

Park, K.S., Ciaraldi, T.P., Abrams-Carter, L., Mudaliar, S., Nikoulina, S.E., Henry, R.R., 1997. PPAR-gamma gene expression is elevated in skeletal muscle of obese and type II diabetic subjects. Diabetes. 46, 1230-1234.

Rendell, M., 2004. The role of sulphonylureas in the management of type 2 diabetes mellitus. Drugs. 64, 1339-1358.

Rosenstock, J., Hassman, D.R., Madder, R.D., Brazinsky, S.A., Farrell, J., Khutoryansky, N., Hale, P.M., 2004. Repaglinide Versus Nateglinide Comparison Study Group. Repaglinide versus nateglinide monotherapy: A randomized, multicenter study. Diabetes Care. 27, $1265-1270$.

Stafylas, P.C., Sarafidis, P.A., Lasaridis, A.N., 2009. The controversial effects of thiazolidinediones on cardiovascular morbidity and mortality. Int. J. Cardiol. 131, 298- 304.

Ting, R.Z., Szeto, C.C., Chan, M.H., Ma, K.K., Chow, K.M., 2006. Risk factors of vitamin B12 deficiency in patients receiving metformin. Arch. Intern. Med. 166, 1975-1979.

Yki-Järvinen, H., 2004. Thiazolidinediones. N. Eng. J. Med. 351, 1106-1118. 